Plant Syst. Evol. 246: 109-125 (2004)

Plant Systematics

DOI $10.1007 / \mathrm{s} 00606-004-0127-1$

and Evolution

Printed in Austria

\title{
Phylogenetic relationships in Carex, subgenus Vignea (Cyperaceae), based on ITS sequences
}

\author{
M. Hendrichs ${ }^{1}$, S. Michalski ${ }^{2}$, D. Begerow ${ }^{1}$, F. Oberwinkler ${ }^{1}$, and F. H. Hellwig ${ }^{2}$ \\ ${ }^{1}$ Universität Tübingen, Botanisches Institut, Lehrstuhl Spezielle Botanik und Mykologie, \\ Tübingen, Germany \\ ${ }^{2}$ Universität Jena, Institut für Spezielle Botanik, Jena, Germany
}

Received August 6, 2003; accepted December 5, 2003

Published online: March 26, 2004

(C) Springer-Verlag 2004

\begin{abstract}
To evaluate the sectional classification in Carex, subgenus Vignea, the ITS region of 58 species of 20 sections was analyzed with Neighbor Joining (NJ) and Markov chain Monte Carlo (MCMC) methods. Sections Dioicae, Physodeae and Ovales are found to be monophyletic, with C. bohemica well integrated in the section Ovales. Section Heleonastes turns out to be monophyletic, if $C$. canescens is treated separately in section Canescentes. Section Elongatae is monophyletic, but C. remota is placed in section Remotae and C. bromoides in section Deweyanae. In both analyses, six representatives of section Arenariae cluster together in a terminal group, whereas $C$. disticha, C. repens and C. siccata form a basal cluster. C. maritima, as the only member of section Incurvae, shares this basal position. C. chordorrhiza is ascribed to section Chordorrhizeae and not ascribed to the paraphyletic section Divisae. C. vulpina and C. otrubae are assigned to section Vulpinae and separated from the heterogeneous section Stenorhynchae. The other members of sections Divisae, Muehlenbergianae, Multiflorae and Stenorhynchae are scattered throughout the trees. The representatives of section Foetidae are dispersed in both analyses, section Paniculatae appears to be non-monophyletic in the molecular results as well.

The subgenus appears subdivided in at least four larger subgroups in all analyses. Whereas these
\end{abstract}

subgroups are strongly supported, the relationships between these subgroups remain only poorly resolved.

Key words: Bayesian analysis, Carex, Vignea, ITS, molecular phylogeny, systematics.

Carex subgenus Vignea (Beauv.) Nees is morphologically characterized by the lack of a prophyll surrounding the base of the axis of partial inflorescence (cladoprophyll), mostly bisexual spikes and usually 2, rarely 3 stigmas. It has been regarded as a natural lineage within the genus Carex L. since the early systematic studies in the 19th century (e.g. Schweinitz 1825, Dumortier 1827, Fries 1835, Kunth 1837, Tuckerman 1843, Drejer 1844). Nearly a quarter of the species of Carex are members of subgenus Vignea. In North America it comprises about one third of the recognized Carex species, in Eurasia estimations reach from 25 to $30 \%$ (Ball 1990, Egorova 1966). In the worldwide monograph of Georg Kükenthal (1909) subgenus Vignea contains 20 sections with 140 species in his broad species concept. Since then, number of species has at least tripled, due to a narrower 
species concept and to new findings especially outside Europe. For North America, 168 species in 17 sections are described (Ball and Reznicek 2002), the Flora of Russia and adjacent countries (Egorova 1999) covers 320 species in 25 sections.

For subgenus Carex, the potential of the ITS region for phylogenetic interpretations on the sectional level was recently demonstrated (Roalson et al. 2001, Hendrichs et al. 2004). For subgenus Vignea, the available molecular data are scarce. Recent molecular studies focused mainly on family and subfamily relationships (Muasya et al. 1998, Yen and Olmstead 2000) or on species of subgenus Carex (Waterway and Olmstead 1998, Starr et al. 1999, Roalson et al. 2001). For better understanding of sectional circumscriptions in subgenus Vignea we analyzed 58 species mainly from northern Europe including sequences of 12 species derived from GenBank (see Table 1).

\section{Materials and methods}

Plant collection and DNA extraction. The analyzed species of Carex are listed in Table 1. Assignment of sections and subsections corresponds mainly to the concept of Kükenthal (1909). Total genomic DNA was isolated from fresh or dried leaf tissue either by crushing the plant material in liquid nitrogen with a micro pestle or by shaking the samples for $3 \mathrm{~min}$ at $30 \mathrm{~Hz}$ (Mixer Mill MM 300, Retsch, Haan, Germany). DNeasy Plant Mini Kit (Qiagen, Hilden, Germany) was used following the manufacturer's protocol.

PCR and sequencing. The ITS region (ITS1, 5.8 S, ITS2; about $700 \mathrm{bp}$ ) was amplified with the primer pair ITSL (Hsiao et al. 1995), ITS5 and ITS4 (White et al. 1990) or ITS5i and ITS4i (Roalson et al. 2001). PCR was performed as described in Hendrichs et al. (2004). The PCR product was purified with QIAquick PCR Purification Kit (Qiagen, Hilden, Germany). The dsDNA obtained was sequenced directly on both strands using the ABI PRISM Big Dye ${ }^{\mathrm{TM}}$ Terminator Cycle Sequencing Ready Reaction Kit (PE Applied Biosystems) on an automated sequencer (ABI 373A, PE Applied Biosystems and LICOR 4000). The sequences of both strands were combined and proof-read with Sequencher ${ }^{\mathrm{TM}} 4.1$ software (Gene Codes Corp., Michigan) and BioEdit (Hall 1999). The sequences reported in this study have been deposited in GenBank (see Table 1). The alignment contained 614 nucleotide sites. After removing ambiguously aligned positions (220-233), 600 sites remained for analyses with 234 variable sites (ITS1: 129, 5.8S: 8, ITS2: 97). The ingroup alone contained 220 variable sites. The alignment is available upon request.

Phylogenetic analysis. DNA sequences were aligned using Clustal X (Jeanmougin et al. 1998). Some manual corrections were done in Se-Al v2.0a7b (Rambaut 2001). The likelihood ratio test as implemented in Modeltest 3.0 (Posada and Crandall 1998) selected $\operatorname{TrN}+\mathrm{G}$ (Swofford et al. 1996) as substitution model (details below). A Bayesian method of phylogenetic inference using a Metropolis-coupled Markov chain Monte Carlo (MCMC) approach was carried out as implemented in the computer program MrBayes (Huelsenbeck and Ronquist 2001) with GTR + I + G (Swofford et al. 1996) as substitution model. Four incrementally heated simultaneous Monte Carlo Markov chains were run over 2000000 generations. Trees were sampled every 100th generation, resulting in an overall sampling of 20000 trees. To obtain estimates for the $a$ posteriori probabilities, a $50 \%$ majority rule consensus tree was computed from those trees that were sampled after the process had reached stationarity (burnin $=2000)$. This Bayesian approach of phylogenetic analysis was repeated five times, always using random starting trees and random starting values for the model parameters to test the reproducibility of the results. Branch lengths were estimated under the maximum likelihood criterion using the same substitution model in PAUP 4.0b10 (Swofford 2002).

Neighbor joining analysis (Saitou and Nei 1987) was done with PAUP 4.0b10 (Swofford 2002) using genetic distances estimated under the maximum likelihood criterion and $\operatorname{TrN}+\mathrm{G}$ as substitution model with the following settings: base frequencies $\mathrm{A}=0.235075, \quad \mathrm{C}=0.273445$, $\mathrm{G}=0.281677, \quad \mathrm{~T}=0.209804 ; \quad$ rate matrix $\mathrm{AC}=1.00000, \quad \mathrm{AG}=2.25212, \quad \mathrm{AT}=1.00000$, $\mathrm{CG}=1.00000, \quad \mathrm{CT}=6.34211, \quad \mathrm{GT}=1.00000$; gamma distribution shape parameter $=0.357885$. Support for internal nodes was estimated by 1000 neighbor joining bootstrap replicates under the 
Table 1. Species analyzed in this study

Species Locality/Voucher ${ }^{\dagger}$

GenBank accession no.

Carex alma L. H. Bailey

Carex appropinquata Schum.

Carex arenaria $\mathrm{L}$.

Carex athrostachya Olney

Carex bicknellii Britton

Carex bohemica Schreb.

Carex bonplandii Kunth

Carex brizoides L.

Carex bromoides Schkuhr

Carex brunnescens (Pers.) Poir.

Carex canariensis Kük.

Carex canescens $\mathrm{L}^{\mathrm{a}}$

Carex canescens $\mathrm{L}^{\mathrm{b}}$

Carex chordorrhiza Ehrh.

Carex curvata Knaf

Carex davalliana Smith

Carex densa L. H. Bailey

Carex diandra Schrank

Carex dioica $\mathrm{L}$.

Carex disticha Lam.

Carex divisa Huds.

Carex divulsa Stokes

Carex duriuscula C.A. Mey.

Carex echinata Murray

Carex elongata L.

Carex foetida All.

Carex fracta Mack.

Carex heleonastes Ehrh.

Carex hoodii Boott

Carex jonesii L. H. Bailey

Carex lachenalii Schkuhr

Carex leavenworthii Dewey

Carex leersii F.W. Schultz

Carex ligerica Gay

Carex loliacea $\mathrm{L}$.

Carex macloviana d'Urv.

Carex macrocephala Willd.

Carex macrorrhiza Boeck.

Carex maritima Gunn.

Carex muricata $\mathrm{L}$.

Carex muskingumensis Schw.

Carex otrubae Podp.

Carex ovalis Good.

Carex paniculata $\mathrm{L}$.

Carex parallela (Laest.) Sommerf.

Carex pinetorum Liebm.
USA, California*

AF285025

Germany; HMH 3358

AY280549

Germany; SMC 126

AY280529

USA, Washington; JM 132

AY280539

USA, Michigan*

Germany; SMC 75

Costa Rica; HeRB 6108

Germany; HMH 503

USA, Tennessee; JE

Sweden; HMH 2776

Spain; HMH 2938

USSR, Siberia*

France; HMH 2282

Sweden; HMH 2804

Germany; SMC 131

Germany; HMH 1413

USA, Washington; JM 161

Denmark; HMH 1931

Germany; HeRB 2185

Germany; FO 8396

France; FO 18408

Germany; HMH 1792

Canada, ${ }^{* *}$

Denmark; HMH 1920

Germany; FO 9351

France; HMH 2292

USA, California*

Germany; HMH 2946

USA, Washington; JM 129

USA, California*

Sweden; HMH 2692

USA, Texas*

France; HeRB 3031

Germany; SMC 120

Sweden; HMH 2955

Sweden; HMH 2957

USA, Oregon*

Argentina, Santa Cruz*

Switzerland; JM 146

Estonia, Muhu Island*

Canada; SMC 181

Germany; HMH 1776

Germany; HMH 1780

Switzerland; HMH 2865

Sweden; HMH 2780

Bolivia; LPB
AF285039

AY280532

AY280563

AY280546

AY280534

AY280567

AY280558

AF284990

AY280550

AY280568

AY280530

AY280542

AY280538

AY280551

AY280543

AY280571

AY280552

AY280553

AF027436

AY280559

AY280560

AY280544

AF285030

AY280566

AY280537

AF285038

AY280564

AF285033

AY280554

AY280531

AY280565

AY280562

AF285017

AF285018

AY280570

AF285036

AY280541

AY280556

AY280561

AY280557

AY280545

AY280540 
Table 1 (continued)

Species Locality/Voucher ${ }^{\dagger}$

GenBank

accession

no.

Carex praecox Schreb.

Germany; SMC 149

AY280527

Carex pseudobrizoides Clavaud

Germany; SMC 97

AY280526

Carex remota $\mathrm{L}$.

Carex repens Bell.

Germany; HMH 3354

AY280548

Poland; SMC 93

AY280528

Carex siccata Dewey

USA, Washington; JM 125

AY280536

Carex spicata Huds.

Germany; HeRB 624

AY280555

Carex stenophylla Wahlenb.

Spain; JM 9772

AY280535

Carex stipata Muehlenb.

Carex vallicola Dewey

USA, Wisconsin; JE

AY280533

USA, Wyoming; FO 31030

AY280569

Carex vernacula $\mathrm{L}$. H. Bailey

USA, Oregon*

AF285022

Carex vulpina $\mathrm{L}$.

Germany; HMH 3359

AY280547

Carex vulpinoidea Michx.

USA, Texas*

AF284968

China, Xinjiang*

USSR, Siberia*

AF284984

Kobresia myosuroides (Vill.) Fiori \& Paol.

Kobresia sibirica (Turcz. ex Ledeb.) Boeck.

USSR, Siberia*

AF284985

AF284986

$\dagger$ Acronyms of herbaria and collections: GOET: Herbarium University Göttingen; HeRB: R. Berndt (private collection); HMH: M. Hendrichs (private collection); FO: F. Oberwinkler (private collection); JE: Herbarium Haussknecht, Jena; JM: J. Müller (private collection); LPB: Herbarium Nacional de Bolivia; SMC: S. Michalski (private collection); TUB: Herbarium Tubingense; WM: W. Maier (private collection);

* Origin of sequence: Roalson et al. 2001

** Origin of sequence: Starr et al. 1999

same model settings. The unrooted phylograms from neighbor joining and MCMC analyses were rooted with three species of the genus Kobresia Willd. from GenBank.

\section{Results}

The different runs of Bayesian phylogenetic analysis yielded consistent results. Stationarity of the Markov chains was reached after approximately 200000 generations of trees, i.e. after 2000 trees had been sampled. Thus, we discarded the first 2000 trees and included 18000 sampled trees in the $50 \%$ majority rule consensus tree of each run. One of them is given in Fig. 1. The phylogram obtained by the NJ analysis is shown in Fig. 2. In both analyses the supported clusters contain the same species, and the tree topology of the MCMC analysis correlates with that of the NJ analysis. In general, statistical support is higher in the MCMC topology than in the
NJ topology (compare Fig. 1 with Fig. 2). Parsimony analyses revealed consistent results, but with lower statistical significance (Hendrichs et al. 2003a).

Rooted with three species of the genus Kobresia, the members of subgenus Vignea group as a highly supported monophyletic lineage. The use of Kobresia as outgroup for our analyses is justified through the results of molecular investigations in the relationship of the genus Carex (comp. Yen and Olmstead 2000, Roalson et al. 2001, Hendrichs et al. 2003b).

The sectional delimitations within subgenus Vignea have been of great difficulty and constant rearrangement since the early approaches. Of the 20 traditionally accepted sections represented in our analyses only sections Dioicae, Physodeae and Ovales are found to be monophyletic. C. bohemica, often placed in section Schellhammeria, appears fully integrated in section Ovales. Section 


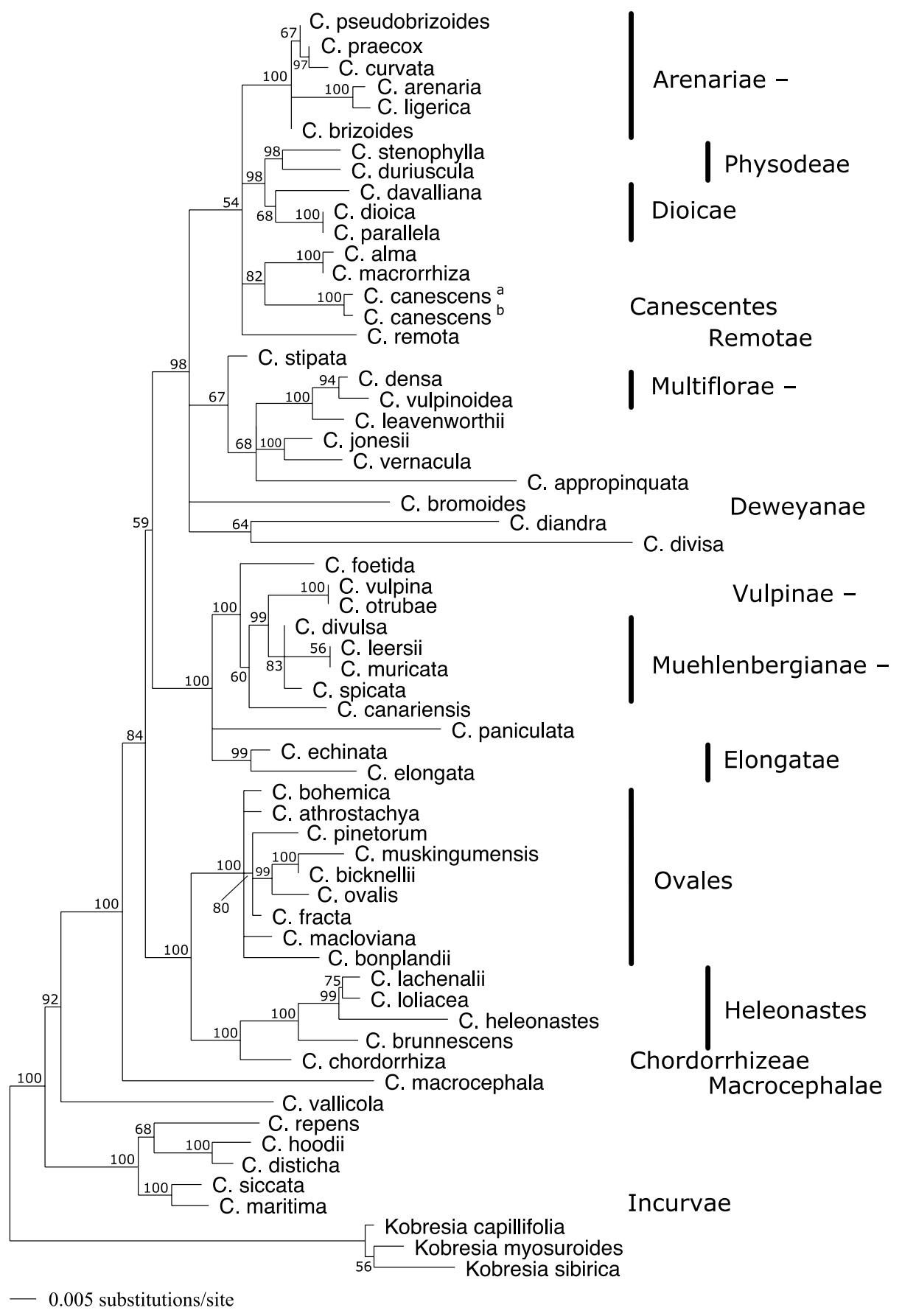

Fig. 1. Bayesian inference of phylogenetic relationships within Carex subgenus Vignea. Metropolis-coupled Markov chain Monte Carlo analysis of an alignment of nuclear sequences from the ITS region using the general time reversible model of DNA substitution with gamma distributed substitution rates and estimation of variant sites. 50\% majority rule consensus tree from 18000 trees that were sampled after the process had reached stationarity. The topology was rooted with three species of the genus Kobresia. The numbers on branches are estimates of a posteriori probabilities. Branch lengths were estimated using Maximum Likelihood and are scaled in terms of expected numbers of nucleotide substitutions per site. The groups marked with "-" do not include all analyzed members of the specified section 


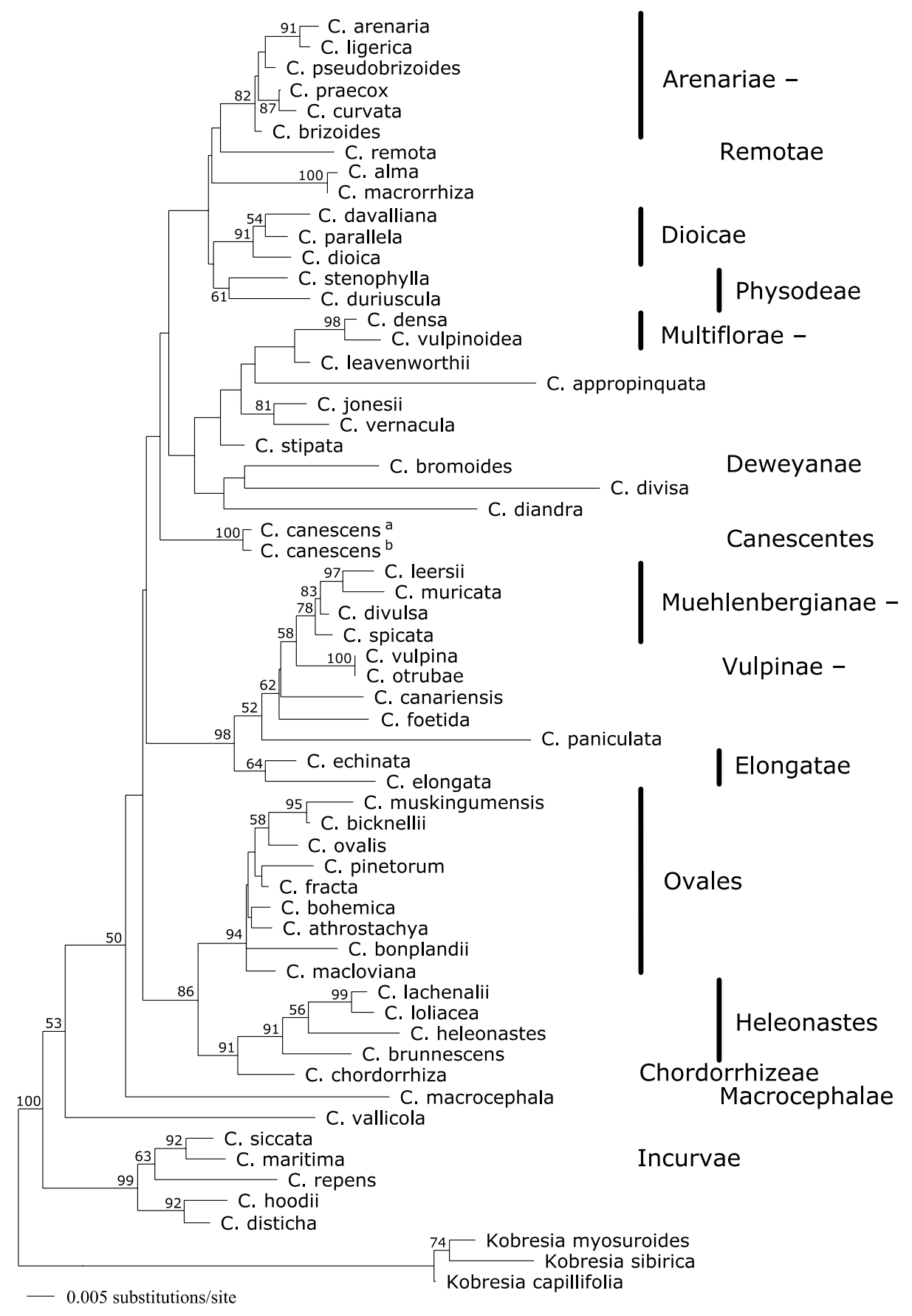

Fig. 2. ITS phylogram of Carex subgenus Vignea obtained by neighbor joining analysis using $\operatorname{TrN}+\mathrm{G}$ as substitution model (parameters are given in the text). The topology was rooted with three species of the genus Kobresia. Percentage bootstrap values of 1000 replicates are given at each furcation values smaller than $50 \%$ are not shown. Branch lengths are scaled in terms of expected numbers of nucleotide substitutions per site. Groups marked with "-" do not include all analyzed members of the specified section

Macrocephalae is represented in our analyses only by $C$. macrocephala. Section Heleonastes is found to be monophyletic, if $C$. canescens is treated in separated section Canescentes. Section Elongatae is marked monophyletic, whereby $C$. remota is placed in section 
Remotae and C. bromoides is referred to section Deweyanae. These two sections are represented by one species each in our dendrograms. In both analyses, six representatives of section Arenaria constitute a well supported group. C. disticha, C. repens and $C$. siccata, traditionally treated in section Arenariae, fall into a basal cluster. C. maritima, as the only member of section Incurvae, shares this basal position in our dendrograms. C. chordorrhiza is referred to section Chordorrhizeae and is not treated in the paraphyletic section Divisae. $C$. vulpina and $C$. otrubae are assigned to section Vulpinae and separated from the heterogeneous section Stenorhynchae. Circumscription of sections Divisae, Muehlenbergianae, Multiflorae and Stenorhynchae was always regarded as very difficult and artificial in larger parts (e.g. Kükenthal 1909, Ball and Reznicek 2002; comp. Table 2). The members of these sections are mainly scattered throughout the trees. If two or three species cluster together, these are labeled in our dendrograms as core-groups, marked with a "-" to indicate that not all analyzed members of the specified section are included. The representatives of section Foetidae are dispersed in both analyses. According to our analyses, section Paniculatae appears to be non-monophyletic as well, even though well-defined by gross morphology.

The ITS region is useful in defining sections within subgenus Vignea and reveals at least four larger subgroups comprising different sections. In a first subgroup species traditionally ascribed to section Arenariae cluster together with $C$. hoodii and $C$. maritima. A second well supported cluster includes members of sections Ovales and Heleonastes together with $C$. chordorrhiza. Species of sections Muehlenbergianae, Vulpinae and Elongatae form a third well supported subgroup with $C$. canariensis, $C$. foetida and $C$. paniculata included. The largest subgroup comprises species of sections Arenariae, Physodae, Dioicae and Multiflorae together with C. remota, C. alma, C. macrorrhiza, C. leavenworthii, C. appropinquata, C. jonesii, C. vernacula, C. stipata, C. bromoides, C. divisa,
$C$. diandra and $C$. canescens. However, the relationships between these subgroups are only weakly supported.

Chromosome numbers of the species studied are listed in Table 2, giving the chromosome counts available in literature.

\section{Discussion}

The sections and species discussed are arranged in order of position in Fig. 1, starting at the base of the dendrogram.

Sections Incurvae, Macrocephalae and related species. A highly supported group in both analyses (a posteriori probability 100\%, bootstrap value $99 \%$ ) comprises $C$. hoodii, $C$. maritima and three species ascribed to section Arenariae by Kükenthal (1909): $C$. siccata, $C$. repens and $C$. disticha. Carex siccata forms a monophyletic group with C. maritima which was placed in the monotypic section Incurvae by Kükenthal (1909). C. disticha is originally an Eurasian endemic, but introduced to North America. It shows closer affinity to $C$. hoodii, which Kükenthal (1909) ascribed to the large and inhomogeneous section Muehlenbergianae. These two subgroups are highly supported (a posteriori probability $100 \%$, bootstrap value $92 \%$ ). Although different sectional classifications for $C$. maritima and $C$. disticha have been proposed (e.g. Egorova 1966, Hylander 1966, Chater 1980, Ball and Reznicek 2002), the group as a whole is not congruent with any existing sectional concept. C. repens is a local endemic species with three disjunct areals in Central Europe, a hybrid origin was sometimes suggested (e.g. Chater 1980). It differs morphologically from $C$. arenaria only by a greater number of spikes and the absence of a scalelike prophyll at the base of spikes. In molecular dendrograms, $C$. arenaria and other members of section Arenariae cluster together as a group at the greatest possible distance in a terminal branch. Interestingly, this group as a whole is characterized by a specific indel in alignment-position 10 and a characteristic sequence pattern in positions 120-123. 
Table 2. Species, sections, and chromosome numbers. The classification mostly follows Kükenthal (1909)

\begin{tabular}{|c|c|c|}
\hline Species & Section & Chromos. no. $(2 n)^{*}$ \\
\hline Carex alma L. H. Bailey & Multiflorae Kunth & \\
\hline Carex appropinquata Schum. & Paniculatae Kunth & 64 \\
\hline Carex arenaria $\mathrm{L}$ & Arenariae Kunth & $56,58,64$ \\
\hline Carex athrostachya Olney & Ovales Kunth & 68 \\
\hline Carex bicknellii Britton & Ovales Kunth & 76,78 \\
\hline Carex bohemica Schreb. & Schellhammeria (Moench) Kunth & $62,64,80$ \\
\hline Carex bonplandii Kunth & Ovales Kunth & \\
\hline Carex brizoides L. & Arenariae Kunth & 58 \\
\hline Carex bromoides Schkuhr & Deweyanae Tuck. & $64,66,68$ \\
\hline Carex brunnescens (Pers.) Poir. & Heleonastes Kunth & 56 \\
\hline Carex canariensis Kük. & Muehlenbergianae Tuck. & 58 \\
\hline Carex canescens $\mathrm{L}^{\mathrm{a}}$ & Canescentes Fries & 54,56 \\
\hline Carex chordorrhiza Ehrh. & Chordorrhizeae Fries & 62 \\
\hline Carex curvata Knaf & Arenariae Kunth & 58 \\
\hline Carex davalliana Smith & Dioicae Tuck. & 46 \\
\hline Carex densa L. H. Bailey & Multiflorae Kunth & \\
\hline Carex diandra Schrank & Paniculatae Kunth & $50,54,60$ \\
\hline Carex dioica $\mathrm{L}$. & Dioicae Tuck. & 52 \\
\hline Carex disticha Lam. & Arenariae Kunth & 62 \\
\hline Carex divisa Huds. & Divisae Christ & $58,60,62$ \\
\hline Carex divulsa Stokes & Muehlenbergianae Tuck. & 56,58 \\
\hline Carex duriuscula C.A. Mey. & Physodeae Christ ex Kük. & 52 \\
\hline Carex echinata Murray & Elongatae Kunth & 56,58 \\
\hline Carex elongata $\mathrm{L}$. & Elongatae Kunth & 56 \\
\hline Carex foetida All. & Foetidae Tuck. & 58 \\
\hline Carex fracta Mack. & Ovales Kunth & \\
\hline Carex heleonastes Ehrh. & Heleonastes Kunth & 56 \\
\hline Carex hoodii Boott & Muehlenbergianae Tuck. & 58,60 \\
\hline Carex jonesii L. H. Bailey & Stenorhynchae Holm & \\
\hline Carex lachenalii Schkuhr & Heleonastes Kunth & $58,62,64,74$ \\
\hline Carex leavenworthii Dewey & Muehlenbergianae Tuck. & \\
\hline Carex leersii F.W. Schultz & Muehlenbergianae Tuck. & 58 \\
\hline Carex ligerica Gay & Arenariae Kunth & 58 \\
\hline Carex loliacea $\mathrm{L}$. & Heleonastes Kunth & 54 \\
\hline Carex macloviana d'Urv. & Ovales Kunth & 82,86 \\
\hline Carex macrocephala Willd. & Macrocephalae Kük. & 74 \\
\hline Carex macrorrhiza Boeck. & Divisae Christ & \\
\hline Carex maritima Gunn. & Incurvae Kük. & 60 \\
\hline Carex muricata $\mathrm{L}$ & Muehlenbergianae Tuck. & 56,58 \\
\hline Carex muskingumensis Schw. & Ovales Kunth & 80 \\
\hline Carex otrubae Podp. & Vulpinae (Carey) Christ & 58,60 \\
\hline Carex ovalis Good. & Ovales Kunth & $62,64,66,68$ \\
\hline Carex paniculata $\mathrm{L}$ & Paniculatae Kunth & $60,62,64$ \\
\hline Carex parallela (Laest.) Sommerf. & Dioicae Tuck. & 43,44 \\
\hline Carex pinetorum Liebm. & Ovales Kunth & \\
\hline Carex praecox Schreb. & Arenariae Kunth & 58 \\
\hline Carex pseudobrizoides Clavaud & Arenariae Kunth & \\
\hline Carex remota $\mathrm{L}$ & Remotae Aschers. & 62 \\
\hline
\end{tabular}


Table 2 (continued)

\begin{tabular}{lll}
\hline Species & Section & Chromos. no. (2n)* \\
\hline Carex repens Bell. & Arenariae Kunth & 70 \\
Carex siccata Dewey & Arenariae Kunth & 70 \\
Carex spicata Huds. & Muehlenbergianae Tuck. & 58,60 \\
Carex stenophylla Wahlenb. & Physodeae Christ ex Kük. & 60 \\
Carex stipata Muehlenb. & Stenorhynchae Th. Holm & 48,52 \\
Carex vallicola Dewey & Muehlenbergianae Tuck. & \\
Carex vernacula L. H. Bailey & Foetidae Tuck. & 68 \\
Carex vulpina L. & Vulpinae (Carey) Christ & 52,54 \\
Carex vulpinoidea Michx. & Multiflorae Kunth & \\
\hline
\end{tabular}

* Chromosome counts compiled from: Böcher 1938; Dalgaard 1991; Davies 1956; Delay 1971; Dietrich 1972; Heilborn 1922, 1924, 1928, 1939; Kjellqvist and Löve 1963; Löve and Löve 1981; Moore and Calder 1964; Moore and Chater 1971; Murín and Májovsky 1976; Naczi 1999; Rothrock and Reznicek 1996; Tanaka 1942a, 1942b, 1948; Whitkus 1981, 1991 and fide FNA 2002

It is worth mentioning that Kükenthal (1909) arranged the monotypic section Incurvae at the beginning of the sections in subgenus Vignea, unfortunately without any explanation. The separation from section Physodeae and section Foetidae is limited to the contour of spikes and the number of spikelets.

In our trees, $C$. vallicola and C. macrocephala appear as members of subgenus Vignea, each in an isolated position. C. vallicola, distributed in pacific North America, is traditionally ascribed to section Muehlenbergianae. This heterogeneous section is divided into almost six different parts in our dendrograms. However, a core group can be detected and is discussed below. C. macrocephala is the only three-stigmatic species integrated in our analyses. The isolated position of this species supports the concept of section Macrocephalae (e.g. Kükenthal 1909, Mackenzie 1931-1935, Ohwi 1936, Egorova 1999, Mastrogiuseppe 2002). On the other hand it can be concluded that $C$. macrocephala and presumably also its East Asian sister taxon C. kobomugi Ohwi are true members of subgenus Vignea. These species can not be separated based on the presence of three stigmata as Kreczetovicz (1935) proposed by establishing the new subgenus Megalocranion Kreczetovicz.

Sections Chordorrhizeae, Heleonastes and Ovales. With the exception of C. chordorrhiza, this group as a whole is characterized by inflorescences with gynaecandrous spikes.

Members of section Heleonastes cluster together, except $C$. canescens, which therefore is referred to as a single member of section Canescentes in our dendrograms. C. lachenalii, known from Europe and North America (as C. bipartita All.) occurs as sister taxon to Eurasian $C$. loliacea, both sharing subarctic distribution. Kükenthal (1909) ascribed C. loliacea to section Tenuiflorae, the sistersection of Canescentes. Later authors (e.g. Mackenzie 1931-1935, Kreczetovicz 1935, Hylander 1966) transferred this species to section Heleonastes in a broader sense, comprising sections Canescentes and Tenuiflorae. $C$. heleonastes, the name-giving species, is connected to them at short distance. Also $C$. brunnescens can be integrated into this highly supported group (a posteriori probability $100 \%$, bootstrap value $91 \%$ ). Surprisingly, the striking morphological similarity between $C$. brunnescens and C. canescens is not reflected by molecular data.

Carex chordorrhiza is characterized by a unique gross-morphology with long-creeping overground tillers and preference of very moist to wet habitats. It was ascribed to section Divisae by most caricologists (e.g. Kükenthal 1909, Mackenzie 1931-1935, Ohwi 1936, Chater 1980, Egorova 1999) and placed in section 
Acroarrhenae, subsection Foetidae by Bailey (1886). Fries (1845) established the section Chordorrhizeae, which was accepted by Mackenzie (1931-35) and Reznicek and Catling (2002) and is used in our dendrograms. The closer relationship to the core group of Heleonastes is well supported in both analyses (a posteriori probability 100\%, bootstrap value $99 \%)$.

Species of section Ovales are distributed mainly in North and South America, from the Arctic to Patagonia, with the greatest diversity in the mountains of the western United States (Reznicek 1993). Kükenthal (1909) listed 21 species in this section, combining many similar taxa as subspecies and varieties under a comprehensive species name. Mackenzie (1931-35) favored a narrow species concept and listed 73 taxa for North America, Mastrogiuseppe et al. (2002) accepted 72 species. In contrast to other sections, the circumscription of section Ovales is rather precise: cespitose growth, spikelets gynaecandrous, perigynia flattened, more or less broadly winged. However, many transitions exist and species-delimitation in this section is therefore rather difficult (Reznicek 1993). Section Schellhammeria is separated from section Ovales only by the smaller perigynium. Therefore the position of $C$. bohemica within section Ovales could be expected and was shown by Roalson et al. (2001) in a smaller species sampling. Bailey (1886) and Mackenzie (1931-35) placed the American sister taxon C. synchnocephala $\mathrm{Ca}$ rey in section Ovales. The densely capitate inflorescence and the protruding leafy lowermost bracts of $C$. bohemica can also be found in species of section Ovales: C. athrostachya is characterized by a leafy basal bract.

The analyzed members of section Ovales form a very homogeneous group with high support in both dendrograms (a posteriori probability $100 \%$, bootstrap value $94 \%$ ). The name-giving Eurasian species $C$. ovalis is naturalized in North America and many other parts of the world. It clusters together with $C$. bicknellii and C. muskingumensis with high support. C. fracta and $C$. pinetorum appear closely related to this core group of Ovales in both dendrograms.

The South American species $C$. bonplandii with scarcely winged perigynium was treated as member of section Elongatae by Kükenthal (1909). It was referred to section Ovales by American authors (e.g. Bailey 1886, Mackenzie 1931-1935). C. pinetorum also has a weakly winged perigynium in comparison with C. athrostachya. Many transitions between wing-structures can be found in section Ovales (Reznicek 1993).

A specimen of C. macloviana from Swedish Lappland was studied. It clusters well in section Ovales, but the relationship to other species of the section remains unresolved. The disjunct distribution of $C$. macloviana and many closely related species in North America (Whitkus and Packer 1984, Whitkus 1988, Mastrogiuseppe et al. 2002) would be worth detailed investigations.

Sections Elongatae, Muehlenbergianae and Vulpinae. The molecularly highly supported cluster (a posteriori probability 100\%, bootstrap value $98 \%$ ) comprises species of different sections.

Carex elongata and C. echinata cluster together with high support, thus showing the difficult separation of section Elongatae from section Muehlenbergianae; the position of $C$. remota is discussed below. According to the molecular data, C. elongata is not closely related to section Canescentes, as was already assumed by Russian authors (Kreczetovicz 1935, Egorova 1966). The achene epidermis, densely covered with nodular protrusions of the many silica bodies (Toivonen and Timonen 1976), shows striking similarity between C. elongata and C. echinata. This morphology strongly supports the grouping based on molecular data.

Carex paniculata is widely distributed in the northern hemisphere, Australia and New Zealand. It is one of the conspicuous sedges growing in large tussocks. Although it appears to be very similar to $C$. appropinquata and $C$. diandra in gross morphology and in 
chromosome number, the three species, classically included in section Paniculatae, appear at separate positions in the molecular trees.

The core group of section Muehlenbergianae, although not highly supported (a posteriori probability $83 \%$, bootstrap value $78 \%$ ), comprises 4 very similar species mainly distributed in Europe. In many floras it is referred to as aggregate of $C$. muricata. $C$. divulsa was introduced in North America and other parts of the world. The distinction to C. leersii is not easy, therefore the latter is often treated as subspecies of $C$. divulsa (e.g. Chater 1980, Sebald 1998). According to ITS data, these two species are well separated. C. leersii, collected in France, seems closely related to C. muricata from Estonia. C. spicata, morphologically characterized by the swollen spongy basal part of the perigynium, is clearly separated in our dendrograms. It is distributed in Eurasia and North Africa and was also introduced to North America. To clarify the circumscription of the fairly diverse section Muehlenbergianae a larger sampling, especially of North American species, is required.

In both analyses, section Vulpinae is a sister group of the core cluster of section Muehlenbergianae. The two species studied, C. vulpina, the True fox sedge and C. otrubae, the False fox sedge, share identical ITS sequences. Thus, the morphologically closely related taxa cannot be distinguished by ITS data.

Carex canariensis, a local endemic of the Canary Islands described by Kükenthal (1900) and referred to section Muehlenbergianae, is a close relative to the group. Kükenthal (1900) postulated differences to $C$. paniculata, which is supported by ITS data.

Carex foetida, the name-giving species of section Foetidae, is distributed in the central and western Alps and the Pyrenees. It is adapted to moist meadows covered by snow for long periods. A basal position in subgenus Vignea, as was supposed by Kükenthal (1909), is not supported by molecular results.

The group including $C$. canariensis, $C$. foetida and the core-groups of sections Muehlenbergianae and Vulpinae is supported in
MCMC analysis with $100 \%$, in NJ with only $62 \%$. It is characterized by an almost stable chromosome number of $2 \mathrm{n}=58$. A single chromosome count of C. vulpina $(2 \mathrm{n}=68)$ has to be verified. Also species of section Arenariae form a highly supported lineage in molecular trees and share a stable chromosome number of $2 n=58$.

Regarding the highly supported larger cluster (a posteriori probability $100 \%$, bootstrap value $98 \%$ ), including $C$. paniculata and section Elongatae, chromosome numbers are rather homogeneous reaching from 56 to 58 , in C. paniculata up to 62 .

Sections Deweyanae, Multiflorae, Remotae, Canescentes, Dioicae, Physodeae and Arenariae. The terminal group appears well supported in MCMC analysis. In NJ analysis C. canescens is placed distantly and the whole cluster is not supported. The unexpected position of $C$. canescens is discussed below.

Carex divisa and $C$. diandra cluster together with $C$. bromoides at a basal position in this terminal group. C. divisa seems closely related to $C$. diandra in MCMC analysis, whereas the NJ dendrogram reveals a closer relationship to $C$. bromoides, both positions without significant support.

In its gross morphology $C$. diandra is a slightly atypical member of section Paniculatae, normally not growing in dense tussocks. The perigynium is significantly smaller than in other Paniculatae-species. There are also micromorphological differences in achene epidermis structures (Toivonen and Timonen 1976). In our molecular tree $C$. paniculata and $C$. appropinquata are separated and belong to different clades.

The next group is weakly supported in MCMC analysis (a posteriori probability $67 \%$ ). It comprises mainly North American species of different traditional sections, indicating that the separation of sections Muehlenbergianae, Stenorhynchae and Multiflorae might be artificial.

Carex stipata is distributed in North America and East Asia and is treated in different sections in the regional floras (e.g. 
Kükenthal 1909, Mackenzie 1931-1935, Ohwi 1936). The only European species in this group is $C$. appropinquata. It is a typical member of section Paniculatae. Gross morphology and ultrastructure of achene epidermis (Toivonen and Timonen 1976) suggest a closer relationship to $C$. paniculata. However, this is not supported by ITS data. The three members of section Paniculatae integrated in our analyses do not appear closely related to each other; yet the unsupported positions in the ITS dendrograms do not allow conclusive groupings.

Carex densa and C. vulpinoidea cluster together, but they are clearly separated from C. alma, the third species of section Multiflorae in our analyses. C. vulpinoidea originated from temperate North America and is naturalized in parts of Europe.

Carex leavenworthii is one of nine species of the inhomogeneous section Muehlenbergianae studied in our analyses. Kükenthal (1909) separated section Muehlenbergianae from section Bracteosae on the basis of rhizome development and the basal structure of the perigynium. Mackenzie (1931-35) united both sections to one species-rich section Bracteosae. Ball (2002) considered section Bracteosae to be endemic to Central and South America and accepted sections Phaestoglochin and Stellulatae for North America, which were established by Egorova $(1966,1999)$ for the Flora of Russia. None of the proposed classifications corresponds with our present molecular results. Therefore only the core group of Muehlenbergianae is labeled in our dendrograms (see above).

The interpretation of $C$. vernacula as an American variety of the European $C$. foetida (e.g. Kükenthal 1909, Reznicek 2002) is not supported by ITS data. C. vernacula and C. foetida appear in distant positions in both dendrograms. The closer relationship between $C$. vernacula and $C$. jonesii is well supported in both analyses (a posteriori probability $100 \%$, bootstrap value $81 \%$ ).

Carex canescens is represented in our analyses by a Siberian and a French specimen differing in only $1 \mathrm{bp}$ in ITS sequence. The distant position of $C$. canescens to other members of section Heleonastes in molecular trees is surprising and was never recognized in other caricological studies. C. canescens is known to hybridize easily with species of nearly all sections in subgenus Vignea (Hylander 1966, Flatberg 1972, Toivonen 1981). This extreme hybridization potential is shared only by $C$. remota and $C$. echinata and is still not understood. Morphological structures of the perigynium and the achene epidermis, (Toivonen and Timonen 1976) cannot be used to explain the exceptional position of $C$. canescens revealed by ITS data either.

Kükenthal (1909) placed $C$. remota in section Elongatae, together with $C$. elongata and $C$. echinata, the latter erroneously named C. stellulata Good. (Kükenthal 1911). Microscopic structures of the achene epidermis in C. remota differ considerably from those of other members of section Elongatae (Toivonen and Timonen 1976), thus supporting our molecular result. C. remota is positioned differently in both analyses, but it has no close relationship to members of sections Elongatae and Canescentes, contrary to what had been postulated by Egorova (1966). We therefore separate sections Remotae and Elongatae in our dendrograms. C. remota is distributed from northern Africa to northern Europe up to $63^{\circ}$ North. It is known as one of the most intensively hybridizing Carex species. $C$. remota hybridizes not only with $C$. arenaria, $C$. brizoides, and $C$. canescens, but also with $C$. appropinquata, C. otrubae, C. divulsa, C. spicata, C. paniculata, C. echinata, C. elongata, and C. ovalis (Kükenthal 1909, Nannfeldt 1977, Toivonen 1981, Jermy et al. 1982, Sebald 1998).

Carex alma, traditionally placed in section Multiflorae, and C. macrorrhiza, ascribed to section Divisae, cluster together with high support. In MCMC analysis these taxa occur in sister position to $C$. canescens.

Carex duriuscula was treated as the Siberian variety of $C$. stenophylla by Kükenthal (1909). In our analyses, these two species are 
well separated by long branches, but show no closer relationship to any other member of section Divisae; therefore we labeled this well supported group as section Physodeae (Chater 1980, Egorova 1999). It occurs in sister position to the three European members of section Dioicae, $C$. davalliana, $C$. dioica and C. parallela.

Kükenthal (1909) placed section Dioicae in subgenus Primocarex. The vast majority of caricologists (e.g. Bailey 1889, Heilborn 1922, Kreczetovicz 1935, Ohwi 1936, Nelmes 1952, Egorova 1966, Toivonen and Timonen 1976, Nannfeldt 1977, Chater 1980, Cochrane 2002) included section Dioicae in subgenus Vignea, which is supported by our data. The terminal spike can consequently be interpreted as a reduced composite spike with only one-dimensional lateral branches. The common hybridization with species of subgenus Vignea (C. canescens, C. maritima, C. lachenalii, C. echinata) was already mentioned by Kükenthal (1909). Additional and independent support for the integration of section Dioicae in subgenus Vignea is lent through the relationship of Carex-specific parasitic smut fungi (e.g. Nannfeldt 1968, 1977). In MCMC analysis, $C$. dioica and $C$. parallela appear closely related, in the $\mathrm{NJ}$ tree a closer relationship of C. davalliana to C. parallela is indicated, as it is also by chromosome numbers (comp. Table 2).

The terminal cluster comprises species ascribed to section Arenariae with Eurasian distribution. This group includes $C$. arenaria as name-giving species and is supported in both analyses (a posteriori probability $100 \%$, bootstrap value $82 \%$ ). A heterogeneous assemblage of species, traditionally placed in Arenariae, was discussed above and is apparently not belonging to the core group as revealed by our data. We concentrate in the following on the well supported terminal Arenariae-group. Within this clade, only $C$. arenaria and $C$. ligerica appear closely related in both analyses. C. arenaria is well adapted to sandy habitats, distributed mainly in the coastal areas of temperate Europe. We studied a specimen from inland sands of eastern Germany. The group as a whole is also characterized by almost similar chromosome numbers of $2 \mathrm{n}=58$ (C. arenaria up to 64$)$.

Carex praecox and $C$. brizoides are well characterized species, distributed in southern and continental Europe except the northern regions. Taxonomically $C$. curvata has been treated differently in European floras. Parent (1974), Chater (1980) and Sebald (1998) considered it as a common hybrid of $C$. praecox and $C$. brizoides. Kükenthal $(1892,1909)$ and Schultze-Motel (1967-1980) treated it as a subspecies of $C$. praecox. Molecular analyses reveal a closer relationship to $C$. praecox than to $C$. brizoides, without giving a clue to the origin of the taxon. C. pseudobrizoides was treated as 'species incertae sedis' by Kükenthal (1909). Chater (1980) presumed identity with C. reichenbachiana Bonnet; Luceño (1994) postulated identity with $C$. brizoides. The phylogenetic position of $C$. pseudobrizoides is not congruent in the two dendrograms; a close relationship with $C$. praecox, as suggested by MCMC analysis, is only weakly supported.

An interesting morphological character of the Arenariae-group is the existence of a scalelike prophyll at the basis of spikes. It appears to be absent in all other species of subgenus Vignea (Kükenthal 1909, Egorova 1999).

\section{General aspects of the subgenus} Vignea. Subgenus Vignea was considered to be a natural group within genus Carex by most caricologists. This morphological concept was recently confirmed by ITS and chloroplast DNA sequence data (Starr et al. 1999, Yen and Olmstead 2000, Roalson et al. 2001).

The delimitation of sections within this subgenus is very difficult and remains artificial in most parts. However, our molecular results allow better sectional circumscriptions and understanding for the species studied. Thus, the relationships between sections are well resolved by ITS sequences, revealing at least four larger subgroups, which are highly supported in all analyses (see above).

Chromosome numbers (Table 2) appear rather homogeneous in subgenus Vignea, not 
indicating whether fission or fusion of polycentric chromosomes was predominant. It is noticeable that two groups revealed by molecular analyses might be characterized by their chromosome numbers. The well supported group including $C$. canariensis, $C$. foetida and the core groups of sections Muehlenbergianae and Vulpinae and also the terminal cluster including members of section Arenariae share a chromosome number of $2 \mathrm{n}=58$.

Although the composition of some sections has become clearer in the course of the present study, no taxonomic conclusions are drawn. As was argued for subgenus Carex (Hendrichs et al. 2004), a worldwide approach is necessary to understand the natural groups within the subgenus Vignea.

Even after 200 years of intensive work in the genus Carex, we are far from understanding the natural delimitations of sections within the well-defined subgenus Vignea. Due to the limited number of species studied so far answer only a few problems could be solved and many open questions remain. Nevertheless, the presented dendrograms can give at least new stimulation for detailed investigations in morphological characters of the species. Ultrastructural data of achene epidermis (Toivonen and Timonen 1976, Starr and Ford 2001) and microscopic features of leaf anatomy (Shepherd 1976) have shown some potential and their exploration should be resumed.

The authors thank R. Bauer, R. Berndt, K.-F. Günther, K. Kiffe, J. Müller and V. Wissemann for the loan of specimens and for helpful discussion, M. Göker and U. Simon for revising the English. Financial support was provided by the Deutsche Forschungsgemeinschaft. This paper is partial fulfillment of the requirements for a $\mathrm{PhD}$ degree for $\mathrm{MH}$, University of Tübingen.

\section{References}

Bailey L. H. (1886) A preliminary synopsis of North American Carices, including those of Mexico, Central America, and Greenland, with the American bibliography of the genus. Proc. Amer. Acad. Arts 22: 59-157.
Bailey L. H. (1889) Carex. In: Gray A. (ed.) The manual of the botany of the Northern United States. American Book Co., New York, pp. 587622.

Ball P. W. (1990) Some aspects of the phytogeography of Carex. Canad. J. Bot. 68: 1462-1472.

Ball P. W. (2002) Section Phaestoglochin. In: Flora of North America Editorial Committee (ed.) Flora of North America. Oxford University Press, New York, pp. 285-297.

Ball P. W., Reznicek A. A. (2002) Carex Linnaeus. In: Flora of North America Editorial Committee (ed.) Flora of North America. Oxford University Press, New York, pp. 254-572.

Böcher T. W. (1938) Zur Zytologie einiger arktischen und borealen Blütenpflanzen. Svensk Bot. Tidskr. 32: 346-361.

Chater A. O. (1980) Carex L. In: Tutin T. G., Heywood V. H., Burges N. A., Valentine D. H., Walter S. M., Webb D. A. (eds.) Flora Europaea. Cambridge University Press, Cambridge, pp. 290-323.

Cochrane T. S. (2002) Section Physoglochin. In: Flora of North America Editorial Committee (ed.) Flora of North America. Oxford University Press, New York, pp. 299-301.

Dalgaard V. (1991) Chromosome studies in flowering plants from Macaronesia II. Willdenowia 20: 139-152.

Davies E. W. (1956) Cytology, evolution and origin of the aneuploid series in the genus Carex. Hereditas 42: 349-365.

Delay J. (1971) Halophytes et écotypes maritimes. Inf. Ann. Caryosyst. Cytogenet. 5: 29-40.

Dietrich W. (1972) IOPB chromosome number reports. XXXVI. Taxon 21: 333-335.

Drejer S. (1844) Symbolae Caricologicae ad synonymiam Caricum extricandam stabiliendamque et affinitates naturales eruendas. Halfniae, Bianco Luno.

Dumortier B. C. J. (1827) Florula Belgica, operis majoris prodomus. Staminatia. Tornati Nerviorum/Tournay.

Egorova T. V. (1966) Osoki SSSR, vidy podroda Vignea (Subgen. Vignea in the U.S.S.R.). Moskva \& Leningrad, Akademija Nauk SSSR.

Egorova T. V. (1999) The sedges (Carex L.) of Russia and adjacent states (within the limits of the former USSR). St. Petersburg, Russian Academy of Sciences, Komarov Botanical Institute. 
Flatberg K. J. (1972) Carex $x$ lidii Flatb. $=$ C. canescens L. x chordorrhiza Ehrh. Norweg. J. Bot. 19: 91-106.

Fries E. M. (1835) Corpus florarum provincialium Sueciae. I. Uppsala, Palmblad, Sebel \& Co.

Hall T. A. (1999) BioEdit: a user-friendly biological sequence alignment editor and analysis program for Windows 95/98/NT. Version 5.0.9. Nucleic Acids Symp. Ser. 41: 95-98.

Heilborn O. (1922) Die Chromosomenzahlen der Gattung Carex. Svensk Bot. Tidskr. 16: 271-274.

Heilborn O. (1924) Chromosome numbers and dimensions, species-formation and phylogeny in the genus Carex. Hereditas 5: 129-216.

Heilborn O. (1928) Chromosome studies in Cyperaceae. I-II. Hereditas 11: 182-192.

Heilborn O. (1939) Chromosome studies in Cyperaceae III-IV. Hereditas 25: 224-240.

Hendrichs M., Michalski S., Begerow D., Oberwinkler F., Hellwig H. (2003a) Phylogenetic relationships in Carex subgenus Vignea (Cyperaceae). 16th Intern. Symposium of the German Bot. Society. Palm. Hortus Francof. 7: 165 (abstract).

Hendrichs M., Begerow D., Oberwinkler F. (2003b) The genus Carex (Cyperaceae) - A phylogenetic hypothesis. 16th Intern. Symposium of the German Bot. Society. Palm. Hortus Francof. 7: 44 (abstract).

Hendrichs M., Oberwinkler F., Begerow D., Bauer R. (2004) Carex, subgenus Carex (Cyperaceae) A phylogenetic approach using ITS sequences. Plant Syst. Evol. (in press).

Hsiao C., Chatterton N. J., Asay K. H., Jensen K. B. (1995) Molecular phylogeny of the Pooideae (Poaceae) based on nuclear rDNA (ITS) sequences. Theor. Appl. Genet. 90: 389-398.

Huelsenbeck J. P., Ronquist F. (2001) MrBayes: Bayesian inference of phylogenetic trees. Bioinformatics 17: 754-755.

Hylander N. (1966) Nordisk kärlväxtflora. Stockholm, Almqvist \& Wiksell.

Jeanmougin F., Thompson J. D., Gouy M., Higgins D. G., Gibson T. J. (1998) Multiple sequence alignment with Clustal X. TIBS 23: 403-405.

Jermy A. C., Chater A. O., David R. W. (1982) Sedges of the British Isles. London, Botanical Society of the British Isles.

Kjellqvist E., Löve A. (1963) Chromosome numbers of some Carex species from Spain. Bot. Not. 116: 241-248.
Kreczetovicz V. I. (1935) Carex L. In: Shishkin B. K., Komarov V. L. (eds.) Flora of the SSSR. Translated from Russian, Israel Program for Scientific Translation, Jerusalem 1964, Leningrad, pp. 111-464/86-369.

Kükenthal G. (1909) Cyperaceae-Caricoideae. In: Engler A. (ed.) Das Pflanzenreich. Engelmann, Leipzig, pp. 1-824.

Kükenthal G. (1911) Einiges über die Bearbeitung der Gattung Carex in J. Briquet, Prodrome de la Flore Corse. Allg. Bot. Z. Syst. 17: 150-151.

Kunth C. S. (1837) Cyperographia synoptica sive enumeratio Cyperacearum omnium hucusque cognitarum, adjectis chracteribus, differentiis et synonymis. In: Kunth C. S. (ed.) Enumeratio plantarum omnium hucusque cognitarum, secudum familias naturalis disposita, adjectis chracteribus, differentiis et synonymis. J. G. Cotta, Stuttgart \& Tübingen, pp. 368-592.

Löve A., Löve D. (1981) Chromosome number reports. LXXIII. Taxon 30: 845-849.

Mackenzie K. K. (1931-1935) Cyperaceae-Cariceae. The New York Botanical Garden, New York.

Mastrogiuseppe J. (2002) Section Macrocephalae. In: Flora of North America Editorial Committee (ed.) Flora of North America. Oxford University Press, New York, pp. 307-309.

Mastrogiuseppe J., Rothrock P. E., Dibble A. C., Reznicek A. A. (2002) Section Ovales. In: Flora of North America Editorial Committee (ed.) Flora of North America. Oxford University Press, New York, pp. 332-378.

Moore D. M., Chater A. O. (1971) Studies of bipolar disjunct species I. Carex. Bot. Not. 124: 317-334.

Moore R. J., Calder J. A. (1964) Some chromosome numbers of Carex species of Canada and Alaska. Canad. J. Bot. 42: 1387-1391.

Muasya A. M., Simpson D. A., Chase M. W., Culham A. (1998) An assessment of suprageneric phylogeny in Cyperaceae using $r b c \mathrm{~L}$ DNA sequences. Plant Syst. Evol. 211: 257-271.

Murín A., Májovsky J. (1976) IOPB chromosome number reports. LIII. Taxon 25: 487.

Naczi R. F. C. (1999) Chromosome numbers of some eastern North American species of Carex and Eleocharis (Cyperaceae). Contr. Univ. Michig. Herb. 22: 105-119.

Nannfeldt J. A. (1968) Fungi as Plant Taxonomists. Acta Univ. Uppsal., 85-95. 
Nannfeldt J. A. (1977) The species of Anthracoidea (Ustilaginales) on Carex subgen. Vignea with special regard to the Nordic species. Bot. Not. 130: 351-375.

Nelmes E. (1952) Facts and speculations on phylogeny in the tribe Cariceae of the Cyperaceae I. General considerations. Kew Bull. 1951: 427-436.

Ohwi J. (1936) Cyperaceae Japonicae I. A synopsis of the Caricoideae of Japan, including the Kuriles, Saghalin, Korea, and Formosa. Memoirs of the College of Science / Kyoto University. Series B 11: 229-530.

Posada D., Crandall K. A. (1998) Modeltest: testing the model of DNA substitution. Bioinformatics 14: 817-818.

Rambaut A. (2001) Se-Al v2.0a72, Sequence Alignment Editor. Oxford UK, University of Oxford.

Reznicek A. A. (1993) Revision of Carex section Ovales (Cyperaceae) in Mexico. Contr. Univ. Michig. Herb. 19: 97-136.

Reznicek A. A. (2002) Section Foetidae. In: Flora of North America Editorial Committee (ed.) Flora of North America. Oxford University Press, New York, pp. 309-311.

Reznicek A. A., Catling P. M. (2002) Section Chordorrhizae. In: Flora of North America Editorial Committee (ed.) Flora of North America. Oxford University Press, New York, pp. 298-299.

Roalson E. H., Columbus J. T., Friar E. A. (2001) Phylogenetic relationships in Cariceae (Cyperaceae) based on ITS (nrDNA) and trnT-L-F (cpDNA) region sequences: Assessment of subgeneric and sectional relationships in Carex with emphasis on section Acrocystis. Syst. Bot. 26: 318-341.

Rothrock P. E., Reznicek A. A. (1996) Documented chromosome numbers 1996: 1. Chromosome numbers in Carex section Ovales (Cyperaceae) from eastern North America. Sida Contrib. Bot.17: 251-258.

Saitou N., Nei M. (1987) The neighbor-joining method: a new method for reconstructing phylogenetic trees. Mol. Biol. Evol. 4: 406-425.

Schweinitz L. D. de (1825) Monograph of the North-American species of the genus Carex. Ann. Lyceum Nat. Hist. New York 1: 283-373.

Sebald O. (1998) Carex L. 1753. In: Sebald O., Seybold S., Philippi G., Wörz A. (eds.) Die Farn- und Blütenpflanzen Baden-Württembergs. Ulmer, Stuttgart, pp. 98-248.
Shepherd G. J. (1976) The use of anatomical characters in the intrageneric classification of Carex (Cyperaceae). Hoehnea 6: 33-54.

Starr J. R., Bayer R. J., Ford B. A. (1999) The phylogenetic position of Carex section Phyllostachys and its implications for phylogeny and subgeneric circumscription in Carex (Cyperaceae). Amer. J. Bot. 86: 563-577.

Starr J. R., Ford B. A. (2001) The taxonomic and phylogenetic utility of vegetative anatomy and fruit epidermal silica bodies in Carex section Phyllostachys (Cyperaceae). Canad. J. Bot. 79: 362-379.

Swofford D. L., Olsen G. J., Waddell P. J., Hillis D. M. (1996) Phylogenetic Inference. In: Hillis D. M., Moritz C., Mable B. K. (eds.) Molecular systematics. Sinauer, Sunderland, pp. 407-514.

Swofford D. L. (2002) PAUP*. Phylogenetic Analysis Using Parsimony (* and Other Methods). Version 4.0b10. Sunderland, Massachusetts, Sinauer Associates.

Tanaka N. (1942a) Chromosome studies in Cyperaceae. XXI-XXIII. Chromosome numbers of Eucarex species (1-3). Med. \& Biol., Tokyo 2: 289-300.

Tanaka N. (1942b) Chromosome studies in Cyperaceae. XXIV-XXVI. Chromosome numbers of Eucarex species (4-6). Med. \& Biol., Tokyo 2: 419-428.

Tanaka N. (1948) The problem of aneuploidy. Biol. Contrib. in Japan 4: 1-327.

Toivonen H. (1981) Spontaneous Carex hybrids of Heleonastes and related sections in Fennoscandia. Acta Bot. Fenn. 116: 1-51.

Toivonen H., Timonen T. (1976) Perigynium and achene epidermis in some species of Carex, subg. Vignea (Cyperaceae), studied by scanning electron microscopy. Ann. Bot. Fenn. 13: 49-59.

Tuckerman E. (1843) Enumeratio methodica caricum quarundam. Species recensuit et secundum habitum pro viribus disponere tentavit. Schenectady, NY State, USA, Isaac Riggs.

Waterway M. J., Olmstead R. G. (1998) Phylogenetic relationships in Carex section Hymenochlaenae inferred from non-coding nuclear and chloroplast DNA sequence data (abstract). Amer. J. Bot. 85: 165.

White T. J., Bruns T. D., Lee S., Taylor J. W. (1990) Amplification and direct sequencing of fungal ribosomal RNA genes for phylogenetics. In: Innis M. A., Gelfand D. H., Sninsky J. J., 
White T. J. (eds.) PCR protocols: A guide to methods and applications. Academic Press, Inc., San Diego, Calif, pp. 315-322.

Whitkus R. (1981) Chromosome numbers of some northern New Jersey Carices. Rhodora 83: 461464.

Whitkus R. (1988) Experimental hybridizations among chromosome races of Carex pachystachya and the related species C. macloviana and C. preslii (Cyperaceae). Syst. Bot. 13: 146-153.

Whitkus R. (1991) Chromosome counts of Carex section Ovales. Bot. Gaz. (Crawfordsville) 152: 224-230.

Whitkus R., Packer J. G. (1984) A contribution to the taxonomy of the Carex macloviana aggregate (Cyperaceae) in western Canada and Alaska. Canad. J. Bot. 62: 1592-1607.
Yen A. C., Olmstead R. G. (2000) Molecular systematics of Cyperaceae tribe Cariceae based on two chloroplast DNA regions: $n d h \mathrm{~F}$ and $\operatorname{trn} \mathrm{L}$ intron-intergenic spacer. Syst. Bot. 25: 479-494.

Addresses of the authors: M. Hendrichs (e-mail: mh@uni-tuebingen.de), D. Begerow, F. Oberwinkler, Universität Tübingen, Botanisches Institut, Lehrstuhl Spezielle Botanik und Mykologie, Auf der Morgenstelle 1, D-72076 Tübingen, Germany. S. Michalski, F. H. Hellwig, Universität Jena, Institut für Spezielle Botanik, Lehrstuhl für Spezielle Botanik, Philosophenweg 16, D-07743 Jena, Germany. 